\title{
Five years' experience of a "prepregnancy" clinic for insulin-dependent diabetics
}

\author{
JUDITH M STEEL, F D JOHNSTONE, A F SMITH, L J P DUNCAN
}

The hazards associated with pregnancy in the insulin-dependent diabetic have altered considerably within the past 60 years. ${ }^{1}$ Nowadays there is rarely a serious risk to the life or health of the mother, while the "classical" grotesquely obese offspring, prone to respiratory distress syndrome and dangerous metabolic disturbance in the neonatal period, is seldom encountered. The frequency of severe congenital abnormalities, however, does not appear to have declined, and this now constitutes the major target for further improvement in the management of the pregnant diabetic. ${ }^{2}$ Most of these abnormalities occur before seven weeks' gestation. ${ }^{3}$ It has been suspected since the observations of Pedersen ${ }^{4}$ that congenital abnormalities are related to poor diabetic control during the early stages of pregnancy, and work in rats has suggested that hyperglycaemia in early pregnancy is associated with a high incidence of congenital abnormalities. ${ }^{5}$ Since the advent of measuring haemoglobin $\mathrm{A}_{1}\left(\mathrm{HbA}_{1}\right)$ as an index of diabetic control, studies have been undertaken and are continuing in several centres to relate the outcome of pregnancy to $\mathrm{HbA}_{1}$ levels during pregnancy. Studies published so far suggest an association between high $\mathrm{HbA}_{1}$ in early pregnancy and congenital abnormalities. ${ }^{6-8}$

This was one of several considerations behind the establishment in Edinburgh towards the end of 1976 of what was probably the first prepregnancy clinic for diabetics. ${ }^{\circ}$ Our five years'

\footnotetext{
Diabetic Department and Department of Clinical Chemistry, Royal Infirmary, Edinburgh, and Simpson Memorial Maternity Pavilion, Edinburgh

JUDITH M STEEL, MB, FRCPED, senior registrar, diabetic department

F D JOHNSTONE, MD, MRCOG, senior lecturer, department of obstetrics

A F SMITH, MD, FRCPATH, senior lecturer, department of clinical chemistry

L J P DUNCAN, MB, FRCPED, consultant physician, diabetic department
}

experience of this clinic, which we now report, has convinced us of its value in assessing factors that can contribute to the better management of pregnancy in the diabetic.

\section{Establishment and aims of the prepregnancy clinic}

Patients were invited to attend the new clinic by personal letters circulated on two occasions to all those women aged between 14 and 40 who were already registered with the diabetic department at Edinburgh Royal Infirmary, and by means of posters displayed in the department. Colleagues were requested to refer appropriate patients, and the subject was raised during consultations both with young women at the Royal Infirmary clinic and with older girls attending the diabetic clinic at the Royal Hospital for Sick Children, Edinburgh. Patients who intend to become pregnant attend the clinic with their partners and are seen on the first occasion by an obstetrician and a physician in joint consultation. On subsequent visits, until pregnancy is established, they are seen by the physician only.

The aims and practices of the clinic are as follows:

(1) To assess individual patients' fitness for pregnancy, particular attention being paid to retinopathy and nephropathy.

(2) To ensure that pregnancies are planned, offering advice on contraception. Based on our survey of practices and experience among the patients attending our diabetic clinic ${ }^{10-13}$ we recommend for most couples the progestogen-only pill or mechanical methods of contraception and female sterilisation when the couple have completed their family.

(3) To identify and if possible treat infertility as early as possible.

(4) To obtain maximum co-operation from patients and their partners, who are given intensive education and invited to put their own questions about the theory and practice of diabetic care during pregnancy. Partners are instructed in the recognition and treatment of hypoglycaemia, including the use of intramuscular glucagon, a supply of which is provided.

(5) To obtain optimum diabetic control before conception. Those patients not already on a twice daily regimen of short-acting and 
intermediate-acting insulins are changed to this regimen. All patients are asked to adhere particularly closely to their prescribed diet, weighing out the carbohydrate content of each meal. Urine tests are carried out four times daily, and for the past three years these tests have been supplemented with home glucose monitoring, using " $\mathrm{B} / \mathrm{M}$ " sticks. Patients are asked to adjust their own insulin dosage to obtain preprandial glucose concentrations of about $4 \mathrm{mmol} / 1 . \mathrm{HbA}_{1}$ measurement became available to us in 1979 and since then has been measured monthly, initially by a method of Kynoch and Lehmann, ${ }^{14}$ slightly modified, ${ }^{15}$ and latterly by an electrophoretic method with the same normal range. ${ }^{16}$ The aim is to attain a level below $10 \%$ and if possible below $8 \%$ (normal range in our laboratory $5 \cdot 9-8.0 \%$ ).

(6) To identify the time of conception. Patients are asked to use mechanical methods of contraception for at least one month after stopping oral contraception and to keep a menstrual calendar. A pregnancy test is done whenever six weeks have elapsed since the last menstrual period. If the first test is negative it is repeated at weekly intervals while amenorrhoea persists.

(7) To identify any gynaecological abnormality, a full abdominal and vaginal examination is carried out.

(8) To check immune status against rubella. Antibody level is measured at the first visit and for those who require it immunisation is offered before conception.

(9) To encourage good general principles of health and hygiene. Patients are particularly advised against smoking and obesity. Since the suggestions that folic $\operatorname{acid}^{17}$ or multivitamin supplements ${ }^{18}$ may reduce the risk of recurrence of neural tube defect we have paid careful attention to dietary advice, but have not so far recommended vitamin supplements.

\section{Experience of the clinic}

Ninety couples have attended the prepregnancy clinic. Eight couples have been advised against pregnancy, 18 have been investigated for infertility, and 46 pregnancies have continued past 20 weeks (three undelivered at the time of reporting). Three couples have moved to other parts of the country.

\section{Patients advised against pregnancy}

Patients attend the clinic, by definition, because they hope to have children. It is therefore only with extreme reluctance that any are advised against pregnancy on medical grounds, but in patients with severe nephropathy the outcome of pregnancy and their own life expectancy is poor. ${ }^{19}$ All eight patients in this category had nephropathy and proliferative retinopathy and some cardiovascular complications of diabetes. Three have in fact since died of their disease. This experience adds weight to our policy of seeking out diabetic girls and young women for prepregnancy counselling to ensure that they recognise the advisability of having their children as early as circumstances will permit.

\section{Infertility}

The frequency of infertility among diabetics is probably not as high as our figure of 18 out of 90 couples might suggest, since many of these couples came forward after years of failure to conceive, when the prepregnancy clinic was opened. Details of the couples and the findings on investigation are given in table $I$. It is disappointing that so far only four pregnancies have ensued in this group.

\section{Effect on motivation}

As table II shows there is a pronounced difference between the prepregnancy patients and the others in the mean gestational age at which they first attended for pregnancy management. Many of our own patients who did not formally come through the clinic had tightened up their control and came to see us as soon as they knew that they were pregnant because they had heard that good care was important. It therefore appears that "heightened awareness" of the need for intensive care before and during pregnancy, which has accompanied the establishment of a prepregnancy clinic, extends even to those who have not actually attended that clinic. It has also been apparent that the enthusiasm with which patients and their partners have co-operated in the demanding process of ensuring close diabetic control during pregnancy has increased over the past five years.

\section{Effect on diabetic control}

Table III shows $\mathrm{HbA}_{1}$ levels throughout the course of the last 46 pregnancies. Control, particularly in early pregnancy, was better in those attending the clinic. To some extent this is predictable, since in many cases the patients were self-selected, and one would expect that patients who knew about the prepregnancy clinic but did not bother to attend to be, in general, poorly motivated and less than assiduous in their attention to the details of their diabetic control. It does not follow, however, that those who did attend were model patients. In several cases attendance denoted that the spirit was willing but did not obscure clinical and biochemical evidence that the flesh was weak. In the last 16 consecutive cases $\mathrm{HbA}_{1}$ was measured when the patients first attended the prepregnancy clinic. The mean $\mathrm{HbA}_{1}$ was $11.7 \%$ (range $9 \cdot 5-16 \cdot 1 \%$ ) at that point, similar to the booking $\mathrm{HbA}_{1}$ of the non-attenders. In addition, by the third trimester the $\mathrm{HbA}_{1}$ levels in the two groups were almost identical. Thus despite selection both initial control and the degree of improvement were similar in the two groups.

\section{Pregnancy outcome}

From 1976, when the prepregnancy clinic started, to 1981 there have been 85 pregnancies where the patient was insulin-dependent before the onset of the pregnancy and where the pregnancy continued after 20 weeks. In 43 pregnancies the woman had attended the pre-

TABLE $\mathrm{I}-$ Findings in 18 infertile couples

\begin{tabular}{lccc}
\hline \multicolumn{1}{c}{ Diagnosis } & No & Treatment & Pregnancy \\
\hline Anovulation & 3 & Ovulation induction (1) & 2 \\
Blocked Fallopian tubes & 2 & Spontaneous ovulation(1) & 0 \\
Oligospermia & 3 & Artificial insemination (2) & 0 \\
All investigations normal & 10 & - & 2 \\
\hline
\end{tabular}

TABLE II-Gestation when first seen during pregnancy (insulin-dependent diabetic pregnancies excluding patients diagnosed during pregnancy and pregnancies ending before 20 weeks)

\begin{tabular}{|c|c|c|c|c|c|c|}
\hline \multirow[t]{2}{*}{ Date } & \multirow[t]{2}{*}{$\begin{array}{l}\text { Total } \\
\text { No }\end{array}$} & & & \multicolumn{2}{|c|}{$\begin{array}{c}\text { Gestation (weeks) } \\
\text { when first seen } \\
\text { pregnant }\end{array}$} & \multirow[t]{2}{*}{$\begin{array}{c}\text { No of } \\
\text { unplanned } \\
\text {-pregnancies }\end{array}$} \\
\hline & & & & Average & Range & \\
\hline $\begin{array}{l}1976 \\
1977\end{array}$ & $\begin{array}{l}16 \\
11\end{array}$ & $\begin{array}{l}\text { Before prepregnancy clinic } \\
\text { Prepregnancy clinic }\end{array}$ & $\begin{array}{r}16 \\
3\end{array}$ & $\begin{array}{r}15 \\
6\end{array}$ & $\begin{array}{l}(6-26) \\
(6-7)\end{array}$ & $\begin{array}{l}5 \\
0\end{array}$ \\
\hline 1978 & 9 & $\begin{array}{l}\text { Others } \\
\text { Prepregnancy clinic } \\
\text { Others }\end{array}$ & $\begin{array}{l}8 \\
6 \\
3\end{array}$ & $\begin{array}{r}15 \\
7 \\
14\end{array}$ & $\begin{array}{l}(8-22) \\
(6-8) \\
(8-19)\end{array}$ & $\begin{array}{l}2 \\
0 \\
0\end{array}$ \\
\hline 1979 & 16 & $\begin{array}{l}\text { Prepregnancy clinic } \\
\text { Others }\end{array}$ & $\begin{array}{r}3 \\
10 \\
6\end{array}$ & $\begin{array}{r}14 \\
7 \\
10\end{array}$ & $\begin{array}{l}(6-8) \\
(8-13)\end{array}$ & $\begin{array}{l}0 \\
0 \\
3\end{array}$ \\
\hline 1980 & 18 & Prepregnancy clinic & 14 & 7 & $(6-8)$ & 0 \\
\hline 1981 & 15 & $\begin{array}{l}\text { Others } \\
\text { Prepregnancy clinic } \\
\text { Others }\end{array}$ & $\begin{array}{r}4 \\
10 \\
5\end{array}$ & $\begin{array}{r}13 \\
7 \\
15\end{array}$ & $\begin{array}{l}(7-16) \\
(6-8) \\
(7-26)\end{array}$ & $\begin{array}{l}0 \\
0 \\
3\end{array}$ \\
\hline
\end{tabular}

Statistics using grouped data of booking times of those attending the prepregnancy clinic were compared with those who did not, using the Mann-Whitney nonparametric test for unpaired data and $\mathrm{p}<0.0000000001$.

TABLE III-Hb $A_{1}$ in 46 insulin-dependent diabetic pregnancies

\begin{tabular}{|c|c|c|c|c|c|c|c|}
\hline \multirow[b]{2}{*}{ Time } & \multicolumn{3}{|c|}{ Prepregnancy clinic $(n=31)$} & \multicolumn{3}{|c|}{ Others $(n=15)$} & \multirow[b]{2}{*}{$\mathbf{p}$} \\
\hline & Mean & SE & $\begin{array}{c}\% \\
\text { Below } \\
8 \%\end{array}$ & Mean & SE & $\begin{array}{c}\% \% \\
\text { Below } \\
8 \%\end{array}$ & \\
\hline $\begin{array}{l}\text { First attended } \\
\text { prepregnancy } \\
\text { clinic }(n=16)\end{array}$ & $11 \cdot 77$ & 0.47 & 0 & & & & \\
\hline $\begin{array}{l}\text { Booking } \\
\text { 1st Trimester } \\
\text { 2nd Trimester } \\
\text { 3rd Trimester }\end{array}$ & $\begin{array}{l}9 \cdot 42 \\
9 \cdot 01 \\
8.05 \\
7.64\end{array}$ & $\begin{array}{l}0.28 \\
0.21 \\
0.12 \\
0.11\end{array}$ & $\begin{array}{l}20 \\
30 \\
58 \\
82\end{array}$ & $\begin{array}{r}11 \cdot 21 \\
10 \cdot 60 \\
9 \cdot 09 \\
7.91\end{array}$ & $\begin{array}{l}0.48 \\
0.34 \\
0.37 \\
0.26\end{array}$ & $\begin{array}{r}0 \\
0 \\
33 \\
63\end{array}$ & $\begin{array}{l}<0.005 \\
<0.001 \\
<0.001 \\
\text { NS }\end{array}$ \\
\hline
\end{tabular}

Normal non-pregnant range $5 \cdot 9-8 \cdot 0 \%$. 
TABLE IV-Major congenital abnormalities in women insulin dependent before the onset of the pregnancy (1976-81)

\begin{tabular}{|c|c|c|c|c|c|c|c|}
\hline $\begin{array}{l}\text { Case } \\
\text { No }\end{array}$ & $\begin{array}{l}\text { Pre- } \\
\text { pregnancy } \\
\text { clinic }\end{array}$ & $\begin{array}{l}\text { White's } \\
\text { classification }\end{array}$ & Clinical details & $\begin{array}{l}\text { Gestation } \\
\text { at delivery } \\
\text { (weeks) }\end{array}$ & 1st Trimester & Defect & Outcome \\
\hline 1 & No & C & $\begin{array}{l}\text { Social and psychological problems. Presented } \\
\text { late in pregnancy. Poor control often } \\
\text { omitted evening insulin }\end{array}$ & 24 & $\begin{array}{l}\text { Presented too } \\
\text { late }\end{array}$ & Anencephaly & Induced abortion \\
\hline 2 & No & $\mathbf{C}$ & Social and psychological problems. Often & 34 & $13.4 \%$ & Sirenomelia (with renal & Neonatal death $(3 \mathrm{~h})$ \\
\hline 3 & No & $\mathbf{R} / \mathbf{F}$ & $\begin{array}{l}\text { omitted insulin in early pregnancy } \\
\text { Proliferative retinopathy treated with } \\
\text { photocoagulation. Nephropathy. } \\
\text { Concealed pregnancy. Very poor control. } \\
\text { Often omitted insulin }\end{array}$ & 34 & $\begin{array}{l}\text { Presented too } \\
\text { late }\end{array}$ & $\begin{array}{l}\text { agenesis) } \\
\text { Sacral agenesis }\end{array}$ & $\begin{array}{l}\text { Urinary incontinence. } \\
\text { Lesion only diagnosed } \\
\text { at age } 3 \text { years }\end{array}$ \\
\hline 4 & No & $\mathbf{R}$ & Proliferative retinopathy treated & 35 & $\begin{array}{l}\text { Before assay } \\
\text { available }\end{array}$ & $\begin{array}{l}\text { Large encephalocele } \\
\text { and microcephaly }\end{array}$ & $\begin{array}{l}\text { Encephalocele surgically } \\
\text { repaired. Good } \\
\text { outcome on current }\end{array}$ \\
\hline 5 & Yes & C & $\begin{array}{l}\text { Well motivated. Previous fetal loss with } \\
\text { multiple haemangiomas }\end{array}$ & 38 & $9 \cdot 5 \%$ & $\begin{array}{l}\text { Transposition of great } \\
\text { vessels, ventricular } \\
\text { septal defect }\end{array}$ & $\begin{array}{l}\text { Died at } 2 \text { months while } \\
\text { undergoing cardiac } \\
\text { surgery }\end{array}$ \\
\hline
\end{tabular}

Class $C=$ Insulin dependent diabetics. Age of onset 10-20 years or duration 10-19 years. No microangiopathy. Class $F=$ Insulin-dependent diabetics. Diabetic nephropathy. Class $R=$ Insulin-dependent diabetics. Proliferative retinopathy.

TABLE V-Deaths after 20 weeks' gestation not due to congenital abnormality

\begin{tabular}{|c|c|c|c|c|}
\hline No & $\begin{array}{l}\text { Pre- } \\
\text { pregnancy } \\
\text { clinic }\end{array}$ & $\begin{array}{l}\text { Gestation } \\
\text { at death } \\
\text { or delivery }\end{array}$ & Outcome & Clinical features \\
\hline 1 & Yes & 26 & Neonatal death $\times 2$ & $\begin{array}{l}\text { Infertility, ovulation induction } \\
\text { with menotrophin (Pergonal). } \\
\text { Hyperstimulation requiring } \\
\text { hospital admission. Eventual } \\
\text { spontaneous rupture of } \\
\text { membranes at } 22 \text { weeks and } \\
\text { abortion of twins at } 26 \text { weeks }\end{array}$ \\
\hline 2 & No & 28 & $\begin{array}{l}\text { Late neonataldeath } \\
\text { (embolisation } \\
\text { from umbilical } \\
\text { catheter) }\end{array}$ & $\begin{array}{l}\text { Referred from another centre. } \\
\text { Previous loss from preterm } \\
\text { delivery. Ritodrine failed to } \\
\text { stop labour }\end{array}$ \\
\hline 3 & Yes & 33 & Stillbirth & $\begin{array}{l}\text { Social and psychological } \\
\text { problems. Adamantly refused } \\
\text { hospital admission for close } \\
\text { fetal surveillance and early } \\
\text { delivery }\end{array}$ \\
\hline
\end{tabular}

pregnancy clinic, in 42 she had not. There were two perinatal deaths in viable pregnancies. In addition, one woman delivered twins at 26 weeks, there was one late neonatal death, and one baby died in the first year of life. Two of these losses were due to congenital abnormality (table IV) and three were due to premature labour and apparently unrelated to diabetes (table V). The final case was a potentially avoidable stillbirth at 33 weeks. This woman had attended the prepregnancy clinic but had social and psychological problems, poc rly controlled diabetes, and adamantly refused hospital admission for close fetal surveillance and possible early delivery.

There were five major congenital abnormalities, including the pregnancies already mentioned (table IV). Four of these occurred in the group of women who had not attended the prepregnancy clinic. In the 46 cases in whom $\mathrm{HbA}_{1}$ was measured, the earliest $\mathrm{HbA}_{1}$ concentration was greater than $13 \%$ in only four cases, and two of these had fetal anomalies.

\section{Patients not attending the clinic}

Among the pregnant diabetics managed by us in the past six years 42 had not attended the prepregnancy clinic. Twenty-one of these delivered or were pregnant during the year in which the clinic started and had not received the information. Eight were referred from other centres already pregnant. Seven (three unmarried) had unplanned pregnancies and six knew about the clinic but did not bother to attend.

Most patients with unplanned pregnancies have been offered and have refused contraceptive advice. This is a difficult group to manage. We are concentrating our efforts on improving control in poorly motivated patients and hope to increase the numbers of these patients coming through the prepregnancy clinic.

\section{Discussion}

Our experience of the prepregnancy clinic is that it contributes to improved management of pregnancy in the diabetic mother by permitting better control of diabetes, particularly at the time of conception and throughout the first trimester, and by encouraging close co-operation between those most closely concerned in the management of the pregnancy (patient, partner, physician, and obstetrician).

Objective evidence of benefit is difficult to obtain. As would be expected, those women who had attended the prepregnancy clinic booked earlier than those who had not. They also had lower $\mathrm{HbA}_{1}$ concentrations in the first trimester, showing that diabetic control had been better during the crucial period of organogenesis, and four of the five congenital abnormalities (and both fatal ones) occurred in women who had not attended the prepregnancy clinic. These groups are not strictly comparable, however, and the single stillbirth occurred in a woman whose co-operation was extremely poor but who had attended the clinic before her pregnancy.

While our data agree with those from London, Boston, and Helsinki ${ }^{6-8}$ in suggesting that tight control of diabetes in the early weeks of pregnancy can reduce the frequency of congenital abnormalities we cannot reasonably expect this figure to fall to zero, since there is an appreciable incidence among the infants of non-diabetic mothers. The outstanding question at present is whether one should strive to achieve $\mathrm{HbA}_{1}$ levels at the time of conception within the normal range. So far we have managed to achieve this in only $20 \%$ of our prepregnancy patients and we hope to improve this figure. Nevertheless, this will be difficult for some patients, as it demands a degree of attention to diet, urine and blood testing, and insulin regimen that few patients can sustain for long. In the prepregnancy clinic we regularly observe that once a couple have decided to have a child the level of diabetic control may be excellent for the first month or two but gradually declines if conception is delayed, which in some cases has been for many months or even years, and many patients have commented that their motivation only really reaches a peak when they know they are pregnant. There is the additional consideration that those diabetics who are most tightly controlled are also at risk of hypoglycaemia, which may be inconvenient and alarming and occasionally even dangerous. We have found that some couples become very upset if they cannot achieve their goal of good control, and some have considered giving up the plan to have a pregnancy. If the goal is even more difficult to achieve this is likely to become an even greater problem. We are planning to attempt to improve control in the more difficult patients by using infusion pumps. Work of Baker et $a l^{20}$ in rats has suggested that even fairly modest degrees of hyperglycaemia may be associated with an increased incidence of congenital abnormalities. As more experience accumulates it may be possible to identify in man an "acceptable" level of $\mathrm{HbA}_{1}$ in early pregnancy below which no further reduction in the incidence of congenital malformations is achieved.

There is no doubt that the information obtained from studying patients in the prepregnancy clinic has enabled us to offer a better service during pregnancy. There are encouraging signs that this in turn is leading to improved motivation, on the 
part of our patients, towards strict diabetic control. We therefore recommend this approach as one means of achieving the collaboration between patient and doctors on which the successful management of diabetes depends.

We are grateful for the help we have received from Dr $R$ Hume and Professor J W Farquhar of the child life and health department.

\section{References}

1 Gabbe SG. Medical complications of pregnancy management of diabetes. Six decades of experience. In: Pitkin RM, Zlatnik FJ, eds. Year book of obstetrics and gynaecology. 1 Obstetrics. Chicago: Year Book Medical Publishers, 1980:37-49.

2 Freinkel N. Of pregnancy and progeny. Diabetes 1980;29:1023-35.

${ }^{3}$ Mills JL, Baker L, Goldman AS. Malformations in infants of diabetic mothers occur before the seventh gestational week. Implications for treatment. Diabetes $1979 ; 28: 292-3$.

4 Pedersen J. The pregnant diabetic and her newborn. Copenhagen: Munksgaard, 1977:196.

5 Deuchar E. Carbohydrate metabolism in pregnancy and the newborn 1978. In: Sutherland $\mathrm{HW}$, Stowers JM, eds. Second Aberdeen international colloquium. Berlin, Heidelberg, New York: Springer-Verlag, 1978: 247-63.

${ }^{6}$ Leslie RDG, John PN, Pyke DA, White JM. Haemoglobin $A_{1}$ in diabetic pregnancy. Lancet 1978; ;i:958-9.

${ }^{7}$ Miller E, Hare JW, Cloherty JP, et al. Elevated maternal haemoglobin $\mathrm{A}_{1 \mathrm{c}}$ in early pregnancy and major congenital anomalies in infants of diabetic mothers. N Engl f Med 1981 ;304:1331-4.

8 Ylinen $\mathrm{K}$, Raivo $\mathrm{K}$, Teramo $\mathrm{K}$. Haemoglobin $\mathrm{A}_{1 \mathrm{c}}$ predicts the perinatal outcome in insulin-dependent diabetic pregnancies. Brf Obstet Gynaecol $1981 ; 88: 961-7$

- Steel JM, Parboosingh J, Cole RA, Duncan LJP. Prepregnancy counselling -A logical prelude to the management of the pregnant diabetic woman. Diabetes Care 1980;3:371-3.

10 Steel JM, Duncan LJP. Serious complications of oral contraception in insulin dependent diabetics. Contraception 1978;17:291-5.

11 Steel JM, Duncan LJP. Contraception for the insulin dependent diabetic. Diabetes Care 1980;3:557-60.

12 Steel JM, Duncan LJP. Experience with the progestogen only contraceptive pill micronor in insulin dependent diabetics. British fournal of Family Planning $1981 ; 6: 108-10$.

13 Gosden C, Steel JM, Ross A. Intrauterine contraceptive devices in diabetic women. Lancet 1982 ; : $530-5$.

14 Kynoch PAM, Lehmann $\mathrm{H}$. Rapid estimation of glycosylated $\mathrm{Hb}$ for routine purposes. Lancet 1977 ;ii:16.

15 Fraser DM, Smith AF, Gray RS, et al. Glycosylated haemoglobin concentrations in newly diagnosed diabetics before and during treatment. Br Med F 1979 ;i:979-81.

16 Read A, Tibi L, Smith AF. Assessment of a simple electrophoretic method for measuring $\mathrm{HbA}_{1}$. Clin Chim Acta 1980;108:487-91.

${ }^{17}$ Lawrence $\mathrm{KM}$, James $\mathrm{N}$, Miller $M$, Campbell $M$. Increased risk of recurrence of pregnancies complicated by fetal neural tube defects in mothers receiving poor diets and possible benefit of dietary counselling. Br Med f 1980;280:1592-4.

18 Smithells RW, Sheppard S, Schoram CJ, et al. Possible prevention of neural tube defects by periconceptional vitamin supplementation. Lancet $1980 ; \mathrm{i}: 339-40$.

19 Pederson J. The pregnant diabetic and her newborn. Copenhagen: Munksgaard, 1977:239.

${ }^{20}$ Baker L, Egler J, Klein S, et al. Meticulous control of diabetes during organogenesis prevents congenital lumbo-sacral defects in rats. Diabetes $1981 ; 30: 955-9$.

(Accepted 11 May 1982)
What might be the cause of frontal alopecia in a young woman?

The commonest cause of frontal alopecia in young women is trauma sustained during hairdressing. Repeated traction with rollers and back-combing will pull the hair out by its roots, and though this will initially result only in thinning of the hair, it will eventually lead to baldness that may be permanent. This effect is usually confined to the margin of the scalp but particularly at the frontal and temporal regions. Sometimes the onset in women of alopecia due to other diseases may start at the frontal margin, but there is usually some thinning of hair on the vertex too. Furthermore, traction alopecia is usually symmetrical. If the trauma is avoided at an early stage there is every likelihood that normal regrowth will take place. Pin-curling instead of rollers may be used if patients still wish to maintain their hair style.-ALAN B SHRANK, consultant dermatologist, Shrewsbury.

\section{What is spinal stenosis, and how is it diagnosed?}

The term spinal stenosis is usually used to describe narrowing of the vertebral canal, the lumbar canal being most commonly affected. Some authors ${ }^{1}$ regard the term as indicating any type of narrowing of the vertebral canal, nerve tunnels, or intervertebral foramina. Verbiest ${ }^{2}$ distinguishes between congenital stenosis due to disturbed fetal development, developmental stenosis due to properties of the neural arch, and acquired stenosis resulting from disc prolapse or the effects of trauma or surgery. Acquired stenosis in Verbiest's experience is often superimposed on pre-existing developmental stenosis. There is a high incidence of stenosis in spines affected by achondroplasia. $^{3}$ Spinal stenosis syndrome usually occurs in the middle-aged or elderly but occasionally in patients in their 20s. Low backache with pain, weakness, or sensory disturbance in the legs on standing or walking with objective signs such as absent tendon reflexes or sensory loss form the clinical picture. To obtain relief the patient has to "undo his lumbar lordosis"' by bending forward, crouching, or sitting with the spine flexed. The peripheral circulation is normal. Myelography may show a complete block but this can be shown only with the spine in extension. ${ }^{5}$ Diagnostic ultrasound is a safe and accurate method of measuring the diameter of the lumbar spinal canal. ${ }^{6}$ When symptoms are severe surgical decompression may be required with multiple laminectomy and facetectomy to relieve constriction of the theca and nerve roots. ${ }^{5}-s$ C GALLANNAUGH, consultant orthopaedic surgeon, Hastings.
1 Arnoldi CC, Brodsky AE, Cauchoix J, et al. Lumbar spinal stenosis and nerve root entrapment syndrome. Definition and classification. Clin Orthop 1976 $115: 4-5$

Verbiest $\dot{H}$. Results of surgical treatment of idiopathic developmental stenosis of the lumbar vertebral canal. A review of 27 years' experience. $\mathcal{F}$ Bone foin Surg 1977;59:181-8.

Nelson MA. Spinal stenosis in achondroplasia. Proc $R$ Soc Med 1972;65:1028-9. South African morphometry and pathological anatomy of the lumbar spine in South African negroes and caucaso

s Newman PH. Surgical treatment for derangement of the lumbar spine. $\mathcal{F}$ Bone foint Surg 1973;55B:7-19.

Porter RW, Ottowell D, Wicks $M$. Use of diagnostic ultrasound for spinal canal measurements. $\mathcal{f}$ Bone foint Surg 1977;59B:249-50.

\section{Can a pregnant woman safely take antimalarial drugs?}

4-aminoquinolone derivatives remain the drugs of choice in the treatment of malaria. Usually chloroquine is used, but where the parasites are resistant quinine sulphate combined with a single dose of pyrimethamine is usually effective. Primaquine, an 8-aminoquinolone derivative, may also be required to eradicate exoerythrocytic parasite. Most antimalarial drugs cause teratogenic effects, but since untreated malaria in a pregnant patient may cause abortion or fetal damage, as well as the risks to the patient herself, treatment is necessary. Where the parasite is sensitive, chloroquine remains the recommended drug. Although this drug crosses the placenta, and there have been a few reports of congenital deafness and chorioretinitis, the risk of treatment is relatively small. There are many more reports about the teratogenic effects of quinine. The risks have probably been exaggerated, however, since most reported fetal abnormalities (principally auditory nerve hypoplasia) occurred with huge doses of quinine when used as abortifacient, and conventional antimalarial doses are probably safe. ${ }^{1}$ Although there are a few case reports of pyrimethamine causing teratogenicity the extensive usage of the drug suggests that risks of treatment are small. ${ }^{2}$ The combination, however, of pyrimethamine with sulfadoxine or dapsone has been shown to be teratogenic in animals, and at present there is inadequate human experience of these combination drugs to justify their use. ${ }^{3}-$ GILLIAN SANDERS, senior registrar in clinical pharmacology, Newcastle upon Tyne.

\footnotetext{
${ }^{1}$ Beeley L. In: Beeley L, Wood SM, eds. Prescribing in pregnancy. London Saunders, 1981 - Schardein J. Drugs as teratogens. Cleveland, Ohio: CRC Press Inc, 1976. Batagol R. The $3 A W$ reference guide on drugs and pregnancy. Melbourne: Roya Women's Hospital, 1980.
} 